\title{
Perlindungan Hukum Terhadap Tenaga Kerja Perempuan Berdasarkan Undang-Undang Nomor 13 tahun 2003 tentang Ketenagakerjaan
}

\author{
Kanyaka Prajnaparamita \\ Fakultas Hukum, Universitas Diponegoro \\ email: anya_fh@yahoo.com
}

\begin{abstract}
Social policies designed to protect female workers that worked at night and promote equality in the workplace have a controversial effect on labor market outcomes. Restrictions on working hours and pregnancy benefits stipulated in applicable laws help protect the responsibilities of women workers who work at night for their families and ensure their physical security, but this regulation can raise doubts about the safety of women working at night. Protection of female workers has been regulated in the Law Number 13 of 2003 concerning Manpower and Decree of the Minister of Manpower and Transmigration Article 76. In addition, the regulation is also regulated in the Transmigration of the Republic of Indonesia No. Kep 224 / Men / 2003 regulates the obligations of employers who employ female workers or laborers, where the application process is carried out directly by the employer through a work agreement between employers and workers which is then supervised by the authorized agency.
\end{abstract}

Keywords: Legal Protection, Women, Working at Night

\begin{abstract}
Abstrak
Kebijakan sosial yang dirancang untuk melindungi pekerja perempuan yang bekerja di malam hari dan mempromosikan kesetaraan di tempat kerja memiliki efek kontroversial pada hasil pasar kerja. Pembatasan jam kerja dan tunjangan kehamilan yang diatur dalam undangundang yang berlaku membantu melindungi tanggung jawab pekerja perempuan yang bekerja di malam hari terhadap keluarganya dan memastikan keamanan fisik mereka, tetapi peraturan ini dapat menimbulkan keraguan terhadap keamanan perempuan yang bekerja pada malam hari. Perlindungan terhadap tenagakerja perempuan telah diatur dalam undang-undang yakni Undang-Undang Nomor 13 tahun 2003 tentang Ketenagakerjaan dan Keputusan Menteri Tenaga Kerja Pasal 76. Selain itu, pengaturannya diatur juga dalam Transmigrasi RI No.Kep 224/Men/2003 mengatur kewajiban pengusaha yang memperkerjakan pekerja atau buruh perempuan, dimana proses penerapanya dilakukan langsung oleh pengusaha lewat perjanjian kerja antara pengusaha dengan tenaga kerja yang kemudian diawasi oleh instansi yang berwenang.
\end{abstract}

Kata Kunci : Perlindungan Hukum, Perempuan, Bekerja di Malam Hari 


\section{A. Pendahuluan}

Negara Indonesia pada saat ini sedang melaksanakan pembangunan disegala bidang. Pembangunan ini meliputi juga pembangunan ketenagakerjaan. Pembangunan ketenagakerjaan merupakan bagian integral dari pembangunan nasional berdasarkan Pancasila dan Undang-Undang Dasar Negara Republik Indonesia Tahun 1945. Perlindungan terhadap perempuan, merupakan hak asasi yang harus diperoleh. Sehubungan dengan hal ini, Pasal 27 ayat (1) UUD 1945, menentukan bahwa setiap warga negara bersamaan kedudukannya di dalam hukum dan pemerintahan dan wajib menjunjung hukum dan pemerintahan itu dengan tidak ada kecualinya. Pernyataan dari pasal tersebut, menunjukkan tidak ada perbedaan kedudukan di dalam hukum dan pemerintahan bagi semua warga negara, baik wanita, pria, dewasa dan anak-anak dalam mendapat perlindungan hukum terutama di bidang ketenagakerjaan/waktu, tempat dan sifat pekerjaannya.

Pentingnya hak asasi manusia (HAM) bagi setiap individu sehingga eksistensinya harus senantiasa diakui, dihargai, dan dilindungi diantaranya melalui berbagai produk perundang-undangan. Adanya pengakuan terhadap eksistensinya hak asasi manusia tertentu membawa konsekwensi pada perlunya diupayakan perlindungan terhadap hak-hak tersebut dari kemungkinan munculnya tindakan-tindakan yang dapat merugikan manusia itu sendiri, baik dilakukan oleh manusia lainnya maupun oleh pemerintah. Salah satu ciri khas pada negara yang disebut rechstaat atau menjunjung tinggi the rule of law, bagi suatu negara demokrasi pengakuan dan perlindungan terhadap hak asasi manusia merupakan satu ukuran tentang baik buruknya suatu pemerintahan. ${ }^{1}$

Pasal 76 Ayat (1), (2), (3), dan (4) Undang-Undang Nomor 13 Tahun 2003 Tentang Ketenagakerjaan memberikan beberapa keringanan kepada pekerja atau buruh perempuan. Keringanan ini diberikan untuk melindungi pekerja atau buruh perempuan karena secara kodrati perempuan mempunyai tugas dan fungsi lain yang lebih mempunyai tugas dan fungsi lain yang lebih penting dalam masyarakat yaitu reproduksi. ${ }^{2}$ Pekerja/buruh perempuan yang berumur kurang dari 18 (delapan belas) tahun dilarang dipekerjakan antara Pukul 23.00 sampai dengan 07.00. Pengusaha dilarang memperkerjakan pekerja/buruh perempuan hamil yang menurut keterangan dokter berbahaya bagi kesehatan dan keselamatan kandungannya maupun dirinya apabila bekerja

\footnotetext{
${ }^{1}$ Romi Asmara \& Laila M. Rasyid, "Perlindungan Hukum Terhadap Anak Perempuan Korban Kejahatan Kesusilaan”, Jurnal Ilmu Hukum, Fakultas Hukum Universitas Riau, Vol. 3 No. 2 Februari-Juli 2013, hlm. 4. ${ }^{2}$ Maimun, Hukum Ketenagakerjaan Suatu Pengantar, PT. Pradnya Paramita, Jakarta, 2007, hlm. 13.
} 
antara Pukul 23.00 sampai dengan 07.00. Pengusaha yang memperkerjakan pekerja/buruh perempuan antara Pukul 23.00 sampai dengan 07.00 wajib: Memberi makanan dan minuman bergizi ini dalam prakteknya tidak sesuai, karena makanan dan minuman berupa puding (pencuci mulut) yang tidak memenuhi 1.400 kalori. Menjaga kesusilaan dan keamanan selama di tempat kerja. Pengusaha wajib menyediakan angkutan antar jemput bagi pekerja/buruh perempuan yang berangkat dan pulang kerja antara Pukul 23.00 sampai dengan 05.00 .

Pada beberapa perusahaan, acapkali mengabaikan peraturan tentang perlindungan terhadap perempuan yang bekerja pada malam hari sebagaimana tidak memenuhi titah Undang-Undang Nomor 13 Tahun 2003 tentang Ketenagakerjaan seperti : tidak menyediakan angkutan antar jemput bagi perempuan yang bekerja pada malam hari, menyalahi regulasi terkait dengan jam lembur, dan tidak memenuhi kesejahteraan makan karyawan sebagaimana sudah ditentukan jumlah yang ideal pada regulasi yang mengatur. Walaupun karyawan atau pekerja wanita yang bekerja pada malam hari ini telah menyatakan kesanggupan diri untuk bekerja sesuai dengan kondisi perusahaan yang tidak menyediakan angkutan antar jemput.

Terhadap kewajiban pengusaha untuk memberikan makanan dan minuman bergizi, Kepmenakertrans 224/2003 mengatur sebagai berikut: Pasal 3: Makanan dan minuman yang bergizi sebagaimana dimaksud dalam Pasal 2 Ayat (l) huruf a harus sekurangkurangnya memenuhi 1.400 kalori dan diberikan pada waktu istirahat antara jam kerja. Makanan dan minuman tidak dapat diganti dengan uang. Berdasarkan uraian tersebut di atas, pada Pasal 76 Ayat (3) dan (4) Undang-Undang Nomor 13 Tahun 2003 Tentang Ketenagakerjaan telah mengatur mengenai makanan dan minuman bergizi, menjaga kesusilaan dan keamanan selama di tempat kerja serta kewajiban pengusaha untuk menyediakan angkutan antar jemput sementara pada kenyataannya hal itu tidak dilakukan oleh perusahaan maka hal ini menjadi dasar ketertarikan penulis untuk membahas tentang "Perlindungan Hukum Terhadap Perempuan yang Bekerja di Malam Hari di Masa Mendatang". Berdasarkan latar belakang yang telah dipaparkan dimuka, ada beberapa permasalahan yang akan dibahas dalam jurnal ini sebagai berikut : Bagaimana perlindungan hukum terhadap perempuan yang bekerja di malam hari dalam hukum positif saat ini ? dan Bagaimana perlindungan hukum terhadap perempuan yang bekerja di malam hari pada masa mendatang. 


\section{Metode Penelitian}

Metode pendekatan yang digunakan penulis dalam penelitian ini adalah metode yuridis normatif karena merupakan penelitian hukum normatif (legal research) atau penelitian hukum doktriner, serta dapat dinamakan penelitian hukum kepustakaan atau penelitian data sekunder (di samping adanya penelitian sosiologis atau empiris yang terutama meneliti data primer).

Pendekatan yuridis normatif ini akan di mulai dari pendekatan terhadap Peraturan Perundang-Undangan dan Aturan-aturan yang mengimplementasikan kebijakan hukum pidana dalam diversi bagi anak pelaku pengulangan tindak pidana. Spesifikasi penelitian yang digunakan dalam penulisan ini adalah deskriptif analitis, yaitu menganalisa permasalahan yang ada sekarang serta menggambarkan semua gejala dan fakta yang ada, berkaitan dengan kebijakan hukum pidana dalam diversi bagi anak pelaku pengulangan tindak pidana.

Dalam penelitian masalah hukum dengan pendekatan yuridis normatif, penelitian ini melakukan pengamatan dengan mempelajari dan menjelaskan data sekunder, yang disebut dengan metode studi kepustakaan. Analisis data pada penelitian ini dilakukan secara kualitatif yaitu dari data yang diperoleh kemudian disusun secara sistematis kemudian dianalisis secara kualitatif untuk mencapai kejelasan pada masalah yang dibahas. Penelitian ini dilakukan dengan mengumpulkan data, menyusun, menganalisis, menginterpretasikan dan kemudian dideskriptifkan. Setelah dilakukan analisis data kemudian dapat diperoleh kesimpulan dengan metode penarikan kesimpulan induktif, yaitu cara berfikir dalam mengambil kesimpulan secara umum yang didasarkan atas faktafakta yang bersifat khusus ${ }^{3}$. Alasan menggunakan analisis kualitatif, karena data yang terkumpul berupa kalimat-kalimat pertanyaan, data yang terkumpul umumnya adalah informasi, hubungan antar variabel tidak dapat diukur dengan angka.

\section{B. Pembahasan}

1. Perlindungan hukum terhadap perempuan yang bekerja di malam hari dalam hukum positif saat ini.

Pasal 50 Undang-Undang No. 13 Tahun 2003 tentang Ketenagakerjaan disebutkan bahwa hubungan kerja terjadi karena adanya perjanjian kerja antara pengusaha dan pekerja. Perjanjian kerja dibuat secara tertulis atau lisan. Menurut

\footnotetext{
${ }^{3}$ Peter Mahmud Marzuki, Penelitian Hukum, (Jakarta: Kencana Predana Media Group, 2005), hlm. 38.
} 
definisi tersebut, hubungan kerja adalah hubungan (hukum) antara pengusaha dengan pekerja (karyawan) berdasarkan perjanjian kerja Dengan demikian, hubungan kerja tersebut adalah sesuatu yang abstrak, sedangkan perjanjian kerja adalah sesuatu yang konkret atau nyata Dengan adanya perjanjian kerja, akan ada ikatan antara pengusaha dan pekerja Dengan perkataan lain, ikatan karena adanya perjanjian kerja inilah yang merupakan hubungan kerja.

Apabila perjanjian kerja yang dibuat oleh pihak-pihak tidak memenuhi dua syarat awal sahnya (perjanjian kerja), yakni tidak ada kesepakatan dan ada pihak yang tidak cakap untuk bertindak maka perjanjian kerja dapat dibatalkan. Sebaliknya apabila perjanjian kerja dibuat tidak memenuhi dua syarat terakhir sahnya (perjanjian kerja), yakni objek (pekerjaannya) tidak jelas dan causa-nya, tidak memenuhi ketentuan maka perjanjiannya batal demi hukum. Pekerja wanita yang masih bekerja sebelum atau sesudah waktu yang telah ditentukan harus mendapat perlindungan. Perlindungan terhadap pekerja wanita di malam hari telah di atur dalam Undang-undang Republik Indonesia Nomor 13 Tahun 2003 tentang Ketenagakerjaan, dimana tertera dalam pasal 76.

\section{Pasal 76}

1) Pekerja/buruh perempuan yang berumur kurang dari 18 (delapan belas) tahun dilarang dipekerjakan antara pukul 23.00 s.d. 07.00.

2) Pengusaha dilarang mempekerjakan pekerja/buruh perempuan hamil yang menurut keterangan dokter berbahaya bagi kesehatan dan keselamatan kandungannya maupun dirinya apabila bekerja antara pukul 23.00 s.d. pukul 07.00 .

3) Pengusaha yang mempekerjakan pekerja/buruh perempuan antara pukul 23.00 s.d. pukul 07.00 wajib:

a. Memberikan makanan dan minuman bergizi; dan

b. Menjaga kesusilaan dan keamanan selama di tempat kerja.

4) Pengusaha wajib menyediakan angkutan antar jemput bagi pekerja/buruh perempuan yang berangkat dan pulang bekerja antara pukul 23.00 s.d. pukul 05.00 .

5) Ketentuan sebagaimana dimaksud pada ayat (3) dan ayat (4) diatur dengan Keputusan Menteri.

Dalam Pasal 76 menjelaskan bahwa pekerja yang tidak memenuhi usia yang ditentukan (kurang dari 18 tahun) tidak diperkenankan bekerja sebelum atau sesudah waktu yang ditentukan dalam undang-undang ini, dimana yang dimaksudkan agar keamanan dari pekerja wanita di malam hari dijamin dan dilindungi oleh undang-undang. Pekerja yang sedang hamil pun diatur pula dalam pasal ini, dimana keterangannya tidak berbeda dengan pasal 76 ayat (1), karna 
mengingat kesehatan kandungan dari pekerja, dimana menurut penjelasan ayat ini waktu tersebut tidak disarankan oleh dokter karna membahayakan bagi wanita hamil.

Pekerja yang bekerja sebelum waktu yang ditentukan harus mendapatkan Fasilitas antar dan jemput, hal tesebut jelas diatur dalam pasal 76 ini. Hal tersebut dikarenakan pada waktu tersebut belum terdapat kendaraan umum dan waktu tersebut rawan terjadi kejahatan.

Keseluruhan dari pasal tersebut memuat tentang keselamatan dari pekerja wanita di malam hari yang merupakan bagian dari hak pekerja. Kemudian dalam undang-undang no.13 tahun 2003 juga menjelaskan kewajiban dari pekerja. Dimana tertera dalam pasal 77 UU no.13 tahun 2003 tentang Ketenaga kerjaan.

\section{Pasal 77}

1)Setiap pengusaha wajib melaksanakan ketentuan waktu kerja.

2)Waktu kerja sebagaimana dimaksud pada ayat (1) meliputi:

a. 7 (tujuh) jam 1 (satu) hari dan 40 (empat puluh) jam 1 (satu) minggu untuk 6 (enam) hari kerja dalam 1 (satu) minggu; atau

b. 8 (delapan) jam 1 (satu) hari dan 40 (empat puluh) jam 1 (satu) minggu untuk 5 (lima) hari kerja dalam 1 (satu) minggu.

3) Ketentuan waktu kerja sebagaimana dimaksud pada ayat (2) tidak berlaku bagi sektor usaha atau pekerjaan tertentu.

4) Ketentuan mengenai waktu kerja pada sektor usaha atau pekerjaan tertentu sebagaimana dimaksud pada ayat (3) diatur dengan Keputusan Menteri.

Dalam pasal ini jelaskan bahwa Pengusaha ataupun majikan harus mengikuti aturan tentang waktu kerja dari pekerja, baik untuk laki-laki maupun perempuan. Pengusaha tidak boleh memperkerjakan pekerjanya lewat dari batas waktu yang telah ditentukan. Ada 3 dasar kebijakan perlindungan tenaga kerja perempuan yang dikategorikan sebagai berikut;

1. Protektif.

Kebijakan perlindungan ini diarahkan pada perlindungan fungsi reproduksi bagi tenaga kerja perempuan, seperti pemberian istirahat haid, cuti melahirkan, atau gugur kandung.

2. Korektif

Kebijakan perlindungan ini diarahkan pada peningkatan kedudukan tenaga kerja perempuan seperti larangan pemutusan kerja bagi tenaga kerja perempuan karena menikah, hamil atau melahirkan. Selain itu juga menjamin tenaga kerja perempuan ajar dilibatkan dalam penyusunan Peraturan 


\section{Perusahaan maupun Perjanjian Kerja Bersama}

3. Non-deskriminasi

Kebijakan perlindungan ini diarahkan pada tidak adanya perlakuan yang bersifat diskriminatf terhadap tenaga kerja perempuan di tempat kerja ${ }^{4}$.

Dimana dari landasan teori-teorinya menjadi landasan aturan dari peraturan tenaga kerja wanita. Dari 3 teori di atas pula menjadi landasan pembuatan perjanjian kerja agar memuat hal-hal tersebut. Proses perlindungan tentang Pekerja Peremouan yang bekerja di malam hari diatur lebih spesifik dalam Keputusan Menteri Tenaga Kerja dan Transmigrasi Publik Indonesia Nomor 224 Tahun 2003 Tentang Kewajiban Pengusaha Yang Memperkerjakan Pekerja/Buruh Perempuan Antara Pukul 23.00 Sampai Dengan 07.00. dalam keputusan menteri ini menteri ini menjelaskan secara terperinci tentang proses perlindungan tenaga kerja perempuan di malam hari.

\section{Pasal 211}

1) Pengusaha yang mempekerjakan pekerja/buruh perempuan antara pukul 23.00 sampai dengan 07.00 berkewajiban untuk:

a. memberikan makanan dan minuman bergizi;

b. menjaga kesusilaan dan keamanan selama di tempat kerja.

2) Pengusaha wajib menyediakan angkutan antar jemput bagi pekerja/buruh perempuan yang berangkat dan pulang bekerja antara pukul 23.00 sampai dengan 05.00 .

Dalam pasal 2 ini menjelaskan bahwa pengusaha harus menyediakan makanan dan minuman bergizi, menjaga keamanan di tempat kerja dan menyediakan angkutan bagi pekerja sehingga keselamatan pekerja perempuan tetap terjamin.aturan yang terdapat dalam pasal 2 tersebut sama dengan Pasal 76 UU no.13 tahun 2003 tentang Ketenaga kerjaan, dimana keduanya mengatur tentang kepentingan dan keselamatan pekerja Perempuan di malam hari.

\section{Perlindungan hukum terhadap perempuan yang bekerja di malam hari di masa mendatang.}

Jenis pembatasan jam kerja yang paling umum adalah larangan kerja malam hari dan batas waktu lembur. Larangan kerja malam membatasi waktu siang hari ketika para pekerja perempuan bekerja sesuai dengan jam kerja biasa, dan batas

\footnotetext{
${ }^{4}$ Sulistyowati Irianto, Perempuan \& Hukum: Menuju Hukum Yang Berperspektif Kesetaraan dan Keadilan, Yayasan Pustaka Obor Indonesia, Jakarta, 2006, Hal., 449- 450.
} 
waktu lembur membatasi jumlah jam kerja para pekerja dalam sehari. ${ }^{5}$ Kedua pembatasan ini menyebabkan perusahaan kurang fleksibel dalam mempekerjakan perempuan. Perusahaan dapat menanggapi pembatasan dengan meningkatkan permintaan waktu lembur tenaga kerja perempuan dalam waktu yang signifikan, dengan asumsi bahwa jam kerja jenis ini dapat diperlakukan secara terpisah. ${ }^{6}$ Namun, perusahaan menjadi terbatas dalam menjalankan produksi dengan permintaan cukup tinggi. Sehingga dikeluarkannya regulasi tentang jam lembur dan persyaratannya oleh UU Ketenagakerjaan memberikan perusahaan peluang untuk mempekerjakan perempaun di malam hari. ${ }^{7}$

Studi lain tentang pembatasan jam kerja telah meneliti dampak pengurangan panjang minggu kerja standar untuk semua pekerja dan menyarankan untuk membatasi pekerjaan lembur. Ketentuan ini menurunkan jumlah patokan jam di mana perusahaan harus membayar premi lembur. Tujuan di balik undangundang ini adalah untuk menghilangkan hari kerja yang terlalu panjang, mempromosikan pembagian kerja, dan menciptakan lapangan kerja. Dampak pengurangan jam standar pada hasil pasar kerja sangat bervariasi di seluruh studi, dan banyak dari pekerjaan ini tidak menekankan perbedaan gender. ${ }^{8}$

Minggu kerja dan menemukan bahwa setiap penurunan satu jam di jam standar menyebabkan penurunan 0,88 ke 1 jam di jam aktual. Penurunan jam lembur menunjukkan pertumbuhan yang signifikan untuk wanita daripada pria, kemungkinan besar mencerminkan kecenderungan wanita untuk bekerja tidak pada malam hari. Hasil juga menunjukkan bahwa pekerja dengan jam standar berkurang mampu menawar kenaikan upah per, hal ini menyebabkan tidak ada kerugian dalam pendaptan bersih. ${ }^{9}$

Karenanya pekerja yang memperoleh pengurangan jam kerja dan upah yang lebih besar membebankan biaya pada orang lain yang kehilangan pekerjaan. ${ }^{10}$

\footnotetext{
${ }^{5}$ Mills, Bradford, and David Sahn. 1997. “'Labor Market Segmentation and the Implications for Public Sector Retrenchment Programs.” Journal of Comparative Economics 25 (3): 385-402.

${ }^{6}$ Card, David, and Alan Krueger. 1995. Myth and Measurement: The New Economics of the Minimum Wage. Princeton, NJ: Princeton University Press.

${ }^{7}$ Nayar, Reema. 1996. “ Indonesian Labor Legislation in a Comparative Perspective: A Study of Six APEC Countries." Policy Research Working Paper 1673. World Bank, Washington, DC.

${ }^{8}$ International Labour Office. 1987. Women Workers: Protection or Equality? Vol. 6, no. 2, Conditions of Work Digest. Geneva: International Labour Office.

${ }^{9}$ Goldin, Claudia. 1988. “ Maximum Hours Legislation and Female Employment: A Reassessment.” Journal of Political Economy 96 (11): 189-205.

${ }^{10}$ Márquez, Gustavo, and Carmen Pagés. 1998. “Ties That Bind: Employment Protection and Labor Market Outcomes in Latin America." Working Paper Series 373. Washington, DC: Inter-American Development Bank.
} 
Pemberian keleluasaan oleh pemerintah terkait dengan jam lembur untuk perempuan diikuti dengan persyaratan yang juga harus dipenuhi oleh perusahaan. Tak jarang, perusahaan melanggar persyaratan tersebut seperti yang seharusnya ditentukan jam lembur dimulai pukul 23.00 masih banyak ditemukan perusahaan yang melaksanakan jam mulai lembur dipercepat satu jam yaitu menjadi 22.00 dengan batas berakhirnya pekerjaan lembur yang tidak disesuaikan namun tetap sama yaitu jam 07.00.

Banyaknya celah dalam pelaksanaan Undang-Undang Ketenagakerjaan juga karena salah satunya pengawasan yang tidak efektif dan tidak adanya sanksi pidana ketika terjadi perbedaan antara pelaksanaan dengan peraturan yang berlaku. Dalam hal ini, terjadi pembiaran oleh pengawas. Undang-Undang Nomor 13 Tahun 2003 menentukan bahwa Pengawasan ketenagakerjaan adalah kegiatan mengawasi dan menegakkan pelaksanaan peraturan perundang-undangan dibidang ketenagakerjaan. Pengawasan ketenagakerjaan dilakukan oleh pegawai pengawas ketenagakerjaan yang mempunyai kompetensi dan independen guna menjamin pelaksanaan peraturan perundang- undangan ketenagakerjaan. Adapun prinsipprinsip pengawasan ketenagakerjaan antara lain:

1. Layanan public

Layanan publik menangani masalah- masalah dan tantangan-tantangan yang dihadapi pengusaha dan pekerja.

2. Akuntabilitas

Staf pengawasan ketenagakerjaan adalah pega-wai negeri yang dijamin hubungan kerjanya dan kemandirian dari pengaruh eksternal yang tidak pantas, baik secara politis maupun finansial. Pengawas ketenagakerjaan harus memiliki akuntabilitas atas tindakan dan kinerja mereka.

3. Efisiensi dan efektivitas

Prioritas ditetapkan atas dasar kriteria yang tepat untuk memaksimalkan dampak.

4. Universalitas

Aspirasi layanan pengawasan ketenagakerjaan adalah untuk mencapai lingkup yang universal, memperluas peranan dan aktivitasnya untuk melindungi sebesar mungkin pekerja di seluruh sektor ekonomi, bahkan pekerja yang diluar hubungan kerja tradisional.

5. Transparansi 
Pengusaha, pekerja dan pemangku kepentingan lainnya diinformasikan atas hak-hak dan tugas-tugas mereka, apa yang diharapkan dari mereka menurut undang- undang, dan apa yang dapat mereka harapkan dari layanan pengawasan ketenagakerjaan.

6. Konsistensi dan koheren

Dalam urusan pengawasan ketena- gakerjaan, pengawas akan memperlakukan kasus yang serupa dengan cara yang serupa menurut kondisi yang serupa untuk mencapai tujuan pencegahan dan kepatuhan yang serupa. Pengawas dalam semua bidang kantor disediakan panduan untuk pendekatan intervensi yang sama, koheren dan konsisten, termasuk dalam pelaksanaan kewenangan, kebijaksanaan dan penilaian.

7. Proporsionalitas

Proporsionalitas berarti mengkaitkan tindak-an penegakan hukum dengan risiko. Penegakan hukum sebanding dengan keseriusan pelanggaran dan risiko potensial atau nyata terhadap kesehatan dan keselamatan. Kapasitas kepatuhan perusahaan diperhitungkan dan cara yang paling sesuai untuk mencapai tujuan kepatuhan yang sama dipertimbangkan.

8. Kesetaraan

Perlindungan yang setara bagi semua pekerja sebanding dengan situasi dijamin oleh undang-undang.

9. Kerjasama

Staf pengawasan bekerjasama dengan organisasi dan badan-badan lain untuk menjamin pelaksanaan hukum ke- tenagakerjaan di perusahaan. Dalam hal ini termasuk organisasi publik dan privat seperti ahli-ahli teknis dan medis, insinyur, lembaga riset, organisasi pendidikan dan pelatihan, polisi dan otoritas pemadam kebakaran, serta sistim peradilan, organisasi asuransi dan lain-lain.

10. Kolaborasi

Staf pengawasan harus berkolaborasi dengan pengusaha dan pekerja dan organisasi mereka di tingkat nasional sektoral dan perusahaan.

Proses Pengawasan yang dilakukan untuk Tenaga kerja perempuan berdasarkan pada UU no.13 tahun 2003 tentang Ketenaga kerjaan dan Keputusan Menteri Tenaga Kerja dan Transmigrasi Publik Indonesia Nomor 224 Tahun 2003 Tentang Kewajiban Pengusaha Yang Memperkerjakan Pekerja/Buruh Perempuan 
Antara Pukul 23.00 Sampai Dengan 07.00, dimana prosesnya diawasi oleh departemen tenaga kerjaan di bawa pengawasan dari kementerian ketenagakerjaan Indonesia.

Dalam pengawasan terhadap undang- undang ketenagakerjaan dilakukan departemen tenaga kerja. Dalam hal ini departemen tenaga kerja melakukan pengawasan berdasarkan aturan yang tertera dalam undang-undang serta berdasarkan perjanjian kerja yang dilakukan antara pengusaha dan tenaga kerja. Proses pengawasan oleh dinas Depnaker dilakukan berdasarkan data yang dilaporkan oleh pengusaha. Selain itu proses pengawasan pun langsung dilakukan oleh petugas dinas depnaker lewat sidak secara mendadak yang dilakukan di perusahaan dari pengusaha, ketika tidak terjadi kesesuaian antara laporan yang diberikan oleh perusahaan dengan hasil lapangan yang didapatkan dari sidak maka akan dilakukan proses hukum. $^{11}$

Proses pengawasan pun tidak akan berjalan dengan baik apabila tenaga kerja yang bersangkutan tidak melakukan laporan ketika terjadi kesalahan, sehingga proses pengawasannya pun tidak hanya dilakukan oleh departemen ketenagakerjaan namun juga oleh pekerja-pekerja wanita yang ada di lapangan. Perlindungan bagi tenaga kerja perem- puan dalam hal waktu kerja dan istirahat Waktu kerja dan istirahat telah sesuai dengan ketentuan Undang-undang No. 13 Tahun 2003, tetapi kerja lembur tidak berdasar kesepakatan antara pengusaha dan tenaga kerja sebagaimana yang ditentukan dalam Pasal 78 ayat (1) huruf a Waktu lembur pun cenderung melebihi ketentuan undang-undang. Namun demikian, terhadap pelanggaran ketentuan ini tidak terdapat pengaturan sanksi bagi perusahaan yang melanggar. Sehingga hak tenaga kerja ini cenderung disimpangi.

Di masa yang akan dating, pelaksanaan peraturan dan perlindungan tenaga kerja perempuan yang bekerja dimalam hari harus diiringi dengan keselarasan antaran pelaksanaan dan penagwasan. Dalam hal ini, penrusahaan haru bersifat koorporatif dengan Disnakertrans sebagai pengawas yang diikuti oleh inisiatif pelaku pekerja lembur untuk melaporkan kesalahan-kesalahan prosedur perusahaan dalam memberlakukan jam lembur kepada pengawas.

Selain itu, perlunya pembaharuan terhadap Undang-Undang Nomor 13 Tahun 2003 tentang Ketenagakerjaan terkait dengan penjatuhan dan pelaksanaan

${ }^{11}$ Zveglich, Joseph, and Yana Rodgers. 1999. " The Impact of Protective Measures for Female Workers.” Mimeo. College of William and Mary, Williamsburg, VA 
sanksi kepada perusahaan yang melanggar ketentuan aturan mempekerjakan perempuan di malam hari berupa sanksi administrative maupun pidana. Sehingga, penegakan perlindungan terhadap pekerja perempuan yang bekerja di malam hari dapat diwujudkan dalam rangka penyetaraan hak perempuan dan perlindungan perempuan.

\section{Simpulan}

Perlindungan hukum terhadap perempuan yang bekerja di malam hari dalam hukum positif saat ini relatif terdapat pelanggaran. Hal ini dikarenakan masih terdapat perusahaan-perusahaan, yang mempekerjakan perempuan dengan waktu kerja yang melebihi waktu yang ditentukan oleh undang- undang dan mengkesampingkan prosedur perlindungan terhadap tenaga kerja perempuan yang bekerja di malam hari.

Perlindungan hukum terhadap perempuan yang bekerja di malam hari dilakukan dengan cara membangun sinergitas antara penyelenggara pekerjaan dengan pengawas serta perempuan yang bekerja dimalam hari terkait dengan penegakan aturan yang berlaku. Sehingga perlindungan terhadap perempuan yang bekerja di malam hari dapat dimaksimalkan dan sesuai dengan prosedur yang diatur dalam peraturan yang berlaku. Perlindungan hukum bagi tenaga kerja perempuan di Indonesia belum cukup memadai. Karena masih terdapat hak- hak tenaga kerja perempuan di Undang-undang No. 13 Tahun 2003, yang apabila dilanggar oleh pengusaha belum ada ketentuan sanksinya. Maka sudah seharusnyalah terdapat peraturan daerah yang mengatur secara spesifik tentang perlindungan HAM terhadap tenaga kerja perempuan yang bekerja di malam hari. Apabila hal ini dilakukan, dimungkin- kan kelemahan-kelemahan yang ada dalam undang-undang dapat tertutup.

Pengawasan perlindungan hukum tenaga kerja (wanita), untuk mengawasi penerapan berlakunya undang-undang yang terkait dengan ketenagakerjaan kepada tenaga kerja maupun perusahaan yang dilakukan oleh pegawai negeri sipil (Kementerian Ketenagakerjaan dan Transmigrasi Daerah/Pusat yang menerima surat tugas), mencakup hak dan kewajiban perusahaan maupun tenaga kerja. Prinsip pengawasan bidang ketenagakerjaan, layanan publik, akuntabilitas, efisiensi dan efektivitas, universal, proporsionalitas, kesetaraan, bagi tenaga pengawas ketenagakerjaan berkewajiban dan tidak menyalahgunakan kewenangannya, memegang kerahasiaan profesionalitas integritas, kemandirian dan imparsialitas, dan berkewenanggan menyelidiki, memberi perintah/melapor kepada penyidik (Polri) untuk ditindaklanjuti dan tetap melakukan koordinasi kepada pimpinan/kepada Kantor 
Ketenagakerjaan, Gubernur, Kabupaten/Kota sebagai atasan.

\section{Daftar Pustaka}

Card, David, and Alan Krueger. 1995. Myth and Measurement: The New Economics of the Minimum Wage. Princeton, NJ: Princeton University Press.

Goldin, Claudia. 1988. "Maximum Hours Legislation and Female Employment: A Reassessment.” Journal of Political Economy 96 (11): 189-205.

International Labour Office. 1987. Women Workers: Protection or Equality? Vol. 6, no. 2, Conditions of Work Digest. Geneva: International Labour Office.

Irianto, Sulistyowati. 2006. Perempuan \& Hukum: Menuju Hukum Yang Berperspektif Kesetaraan dan Keadilan, Yayasan Pustaka Obor Indonesia, Jakarta.

Maimun, Hukum Ketenagakerjaan Suatu Pengantar, PT. Pradnya Paramita, Jakarta, 2007

Márquez, Gustavo, and Carmen Pagés. 1998. “ Ties That Bind: Employment Protection and Labor Market Outcomes in Latin America." Working Paper Series 373. Washington, DC: Inter-American Development Bank.

Marzuki, Peter Mahmud. 2005. Penelitian Hukum, Jakarta: Kencana Predana Media Group.

Mills, Bradford, and David Sahn. 1997. "Labor Market Segmentation and the Implications for Public Sector Retrenchment Programs.” Journal of Comparative Economics 25 (3): 385-402.

Nayar, Reema. 1996. "Indonesian Labor Legislation in a Comparative Perspective: A Study of Six APEC Countries.” Policy Research Working Paper 1673. World Bank, Washington,

Romi Asmara \& Laila M. Rasyid, "Perlindungan Hukum Terhadap Anak Perempuan Korban Kejahatan Kesusilaan", Jurnal Ilmu Hukum, Fakultas Hukum Universitas Riau, Vol. 3 No. 2 Februari-Juli 2013

Zveglich, Joseph, and Yana Rodgers. 1999. “ The Impact of Protective Measures for Female Workers.” Mimeo. College of William and Mary, Williamsburg, VA 